\title{
Организация социальной работы
}

Цветкова Л.А.

\section{Вуз как социально-организационная среда превенции молодежного наркопотребления}

B cmaтье поднимаются важные вопросы, связанные $c$ обучением и воспитанием студентов в вузе. Обосновывается необходимость демократических основ воспитательного прочесса. Особое внимание автором уделяется влиянию социальноорганизационных характеристик вуза на психическое здоровье студентов. Анализируются факторы, оказывающие влияние на наркотизм и отмечается необходимость профилактических мероприятий: обеспечение возможности для студентов получить психологическую помощь;; разработка и внедрение программ по обучению управлением стрессом.

Ключевые слова: воспитание, подходы к организации учебного прочесса, психическое здоровье студентов, стресс, превентивные программы.

Под образованием в Законе Российской Федерации об образовании понимается целенаправленный процесс обучения и воспитания в интересах личности, общества, государства, сопровождающийся констатацией достижения гражданином (обучавшимся) определенных государством образовательных уровней (образовательных цензов).

Согласно А.А. Реану [6] «...конечной целью любой образовательной системы является обучение, воспитание и развитие личности учащихся». Обучение предполагает передачу суммы знаний и навыков, минимально достаточной, чтобы справляться с некоей специальной профессиональной деятельностью. Образование же подразумевает не только обучение, но и развитие способностей учащегося, формирование его как личности и как субъекта деятельности.

Понятие «воспитание» в истории педагогики имело различные значения в тот или иной исторический период. Начиная с известных экспериментов К.Левина, проведенных в1938 г., и направленных на 
изучение влияния стиля общения и руководства учителя на эффективность процессов обучения и воспитания, проблема изучения факторов, влияющих на развитие личности учащегося и формирование межличностных отношений в учебной группе остается высоко актуальной. Вместе с развитием психологии как дисциплины, менялись воспитательные акценты и в образовательных программах [5]. Это:

- значимость общения, заботы и умения слушать (Х.Жино, 1965);

- воспитание ответственности и внутренней дисциплины, умения более объективно оценивать реальность и адекватно реагировать на трудности, деликатность и способность оказывать поддержку (У.Глассер, 1965);

- подчеркивание социальной природы человека, акцент на компетентности и демократических принципах воспитания (Р.Дрейкурс, 1967);

- внимание к эффективности воспитательных воздействий, осознание взаимозависимости между поведением ученика и отношением воспитателя, различие между авторитетом и авторитарностью, анализ защитных реакций детей на применение взрослыми силы (открытое неповиновение, мстительность, агрессивность, уход в себя, озлобленность, покорность, ложь, некоммуникабельность, избегание и др.) (Т.Гордон, 1970);

- значимость установления позитивных взаимоотношений и умения формулировать поведенческие цели и прогнозировать последствия поведения с учетом результатов исследований в области влияния внутренней и внешней мотивации на эффективность обучения (Динкмейер и МакКей, 1976).

Сегодня на смену эпохе контроля и доминирования в воспитании приходит время понимания, влияния и убеждения. В авторитарном подходе подчеркивается произвольность отождествления системы провозглашаемых нравственных ценностей с нормами, которыми руководствуется сам воспитатель, рассматривающий себя как нравственный эталон, отношения между воспитателем и учащимся определяются в терминах господства и подчинения. Поэтому авторитарный подход к организации учебного процесса проявляется в преобладании тенденции к полному контролю учителя над его целями и содержанием, общение в учебном процессе сводится к вопросам и ответам, взаимодействие между участниками не предусматривается.

Демократический подход в воспитании базируется на принципах равенства и взаимного уважения. Равенство здесь не означает тождества, речь идет о равенстве человеческой ценности и 
достоинства воспитателя и ученика. Данный подход допускает возможность выбора и свободу самоопределения в рамках установленных норм и ограничений, акцентирует внимание на воспитании личной ответственности и самодисциплины.

В рамках демократического подхода предполагается сотрудничество между учителем и учащимися в разработке позитивной учебной среды. Учащиеся обнаруживают внутреннюю самодисциплину и нуждаются в минимальном внешнем контроле со стороны учителя. «В интересах выживания человечества, должны быть отвергнуты как несостоятельные традиционные формы социальной организации, опирающиеся на прямое принуждение, социально-экономическое или национальное господство. На их место выдвигаются идеи солидарного развития, социокультурной толерантности, глобальной социально-экологической дисциплины и прагматизма, институциональное закрепление права и морали в международных институциях» [4]. T.о., в современном образовательном процессе, наряду с важностью целей, связанных с передачей академических знаний, не меньшее значение имеет развитие учащегося как личности и субъекта деятельности. Как отмечает А.А.Реан [6], это обязательно развитие:

- интеллекта;

- эмоциональной сферы;

- устойчивости к стрессорам;

- уверенности в себе и самопринятия;

- позитивного отношения к миру и принятия других;

- самостоятельности, автономности;

- мотивации самоактуализации и самосовершенствования.

К.Роджерс [7], анализируя влияние образовательной среды на эффективность обучения, пришел к выводу о том, что в развивающей личность ситуации большое внимание уделяется человеческому достоинству, возможности личного выбора, воспитанию ответственности и радости творчества. В качестве примера организации на практике здоровой образовательной среды, характеризующейся позитивным психологическим климатом и успехами в обучении, Рождерс описывает эксперимент, проведенный в 1977 году в Университете св.Лоуренса. В эксперименте принял участие факультет геологии, который на определенное время ввел несколько новых правил в учебный процесс:

Взамен стандартных курсов ввели независимую работу над проектами. 
Студенты самостоятельно оценивали свою работу. Экзамены не проводились. В качестве альтернативного средства демонстрации своих достижений студенты комплектовали «портфель» своих работ.

Студентам была предоставлена возможность принимать участие в вопросах, связанных с управлением факультетом.

Предметы «геология» и «география» получили максимально широкую трактовку. Студенты самостоятельно разрабатывали личные учебные планы.

Кафедры совместно со студентами взяли на себя ответственность за создание и сохранение содержательного багажа и стимулирующей образовательной среды для пользы каждого.

Все происходящее базировалось на договорной основе, студенты и преподаватели условились не пытаться оказывать давление, манипулировать или контролировать кого бы то ни было.

Договорились также о стремлении создать и поддерживать открытые контакты, способствующие взаимному уважению, дружбе и взаимопомощи в отношениях.

Горизонтальная административная структура обеспечила участникам равные возможности, авторитет, полномочия. Функция председателя заключалась в координации с целью интеграции горизонтально организованных групп в более широкие университетские структуры, организованные в жесткую вертикальную иерархию. Председательство предусматривало ротацию.

Факультет из преимущественно профессионально ориентированного преобразован в более либеральное учебное заведение, где общим знаниям о Земле придавалось не меньшее значение, чем профессиональной подготовке узких специалистов в области геологии и географии. Т.о., те, кто готовит себя к занятиям бизнесом, политикой или к любой другой карьере, могли иметь возможность расширить свои знания о Земле.

На протяжении пяти лет были предприняты изменения, связанные с восстановлением некоторых курсов и заново введена система оценки таких параметров как вклад и участие. В итоге, программа приобрела двойственную форму, при которой $60 \%$ студентов работали в группах, ориентированных на проекты, а остальные занимались в более традиционной манере.

В условиях постоянно возрастающего количества информации, технического прогресса и быстрых изменений в мире, организации вынуждены находиться в процессе постоянного обучения. Э. Шейн [8] рассматривает организационную культуру как обучающуюся с целью и в направлении управления противоречиями между стабильностью и изменениями. Можно ли стабилизировать 
непрерывное обучение и изменения? Как будет выглядеть культура, в которой поощряется обучение? Каким образом организационная культура может стать постоянно обучающейся системой? В ответах на эти вопросы присутствуют следующие ценностные представления:

- мир управляем, обучающая культура должна содержать базовое общее представление о том, что состояние среды, в которой она существует, в некоторой степени поддается управлению;

- прогнозирование и активное решение проблем как последовательный процесс обучения в противовес конкретным решениям частных проблем;

- представление о том, что решения проблем находятся в процессе поиска истины, источником которой может быть наука, опытные практики и экспериментирование, - знания и навыки таким образом приобретают множество форм;

- представление об обучении как стремлении к выживанию и совершенствованию, при котором люди имеют конструктивные намерения и способны к обучению и изменениям;

- ситуативный подход в решении вопросов об эффективности организации в зависимости от индивидуализма-коллективизма, ориентации на задачи- ориентации на отношения и авторитаризмаколлегиальности, при условии, что они основаны на доверии;

- оптимальная временная ориентация для обучения ближайшее будущее;

- предположение о значимости коммуникации и информации для успешности обучающей организации;

- обучающая культура предполагает разнообразие и взаимосвязанность субкультур организации;

- важность для обучения умения мыслить системно, отказ от линейной логики в пользу сложных когнитивных моделей.

Таким образом, организационная культура и организационные ценности детерминируют потенциал обучения организации, а следовательно, и ее адаптивность во внешней среде.

Влияние социально-организационных характеристик вуза на психическое здоровье студентов.

В течение последнего десятилетия одной из самых сложных и важных проблем российского общества, которая в значительной мере затрагивает и вузы, является проблема здоровья молодого поколения.

Согласно Закону Российской Федерации об образовании, право на получение образования, является одним из основных и неотъемлемых конституционных прав граждан Российской Федерации. Между уровнем образования и здоровьем людей существует тесная взаимосвязь. Уровень образования влияет на 
отношение к людей к своему здоровью, повышает вероятность выбора «здорового» поведения.

Связь между образованием и здоровьем опосредуется экономическими факторами. Бедность и низкое образование коррелируют с плохим состоянием здоровья. В целом, чем выше уровень образования, тем лучше здоровье людей, надо, однако, заметить, что хорошее образование обычно связано с высоким заработком [2]. Связь образования и здоровья в экономически развитых странах обеспечивается и функционированием правовой системы. В международных документах право на здоровье обязывает правительственные органы предоставлять населению информацию в области здравоохранения. Таким образом, право на здоровье оказывается взаимосвязанным с правом на образование, поскольку речь идет об образовании в сферах жизни, связанных со здоровьем [1]. Высшие учебные заведения, как социальные институты обладают сегодня достаточным опытом и научным потенциалом для того, чтобы внести свой вклад в решение социально значимых теоретических и прикладных проблем в области общественного здоровья.

Одной из наиболее важных задач общественного здравоохранения в России сегодня является разработка концепции профилактики наркозависимости среди подростков и молодежи, внедрение соответствующих образовательных программ для студентов, подготовка специалистов в области профилактики аддиктивного поведения.

Профилактика в широком смысле этого понятия ставит своей основной целью повышение качества жизни. «Здоровье», которое определяется Всемирной организацией здравоохранения как гармоничное сочетание физического, психического и социального благополучия, во многом связано с качеством жизни. Модель общественного здравоохранения, разработанная Всемирной организацией здравоохранения рассматривает употребление психоактивных веществ как результат взаимодействия между личностью (потребителем), наркотиком (психоактивным веществом) и окружающей средой.

Исследование и анализ огромного количества разнообразных факторов, оказывающих влияние на наркотизм; разработка и внедрение профилактических программ возможны только на основе взаимодействия специалистов разных профессиональных областей деятельности. На уровне вуза эти задачи требуют интеграции усилий многих подразделений, объединения администрации, ученых, преподавателей и студентов на пути эффективного предупреждения наркопотребления. 
Профилактика наркотизма в рамках общей проблемы здоровья стала особенно актуальной в сегодняшних сложных социальных и экономических условиях. Студенты оказались одной из наименее социально защищенных категорией населения. Влияние социальноэкономических условий на здоровье студентов можно описать, используя понятие стресса, поскольку он занимает одно из первых мест среди факторов, влияющих на здоровье студентов.

Т.н. «витаминная» модель стресса постулирует, что наиболее высокие и наиболее низкие показатели переживаемого стресса, т.е. когда люди чувствуют себя недостаточно нужными и востребованными, или им кажется, что выполняемая ими деятельность недостаточно социально важна коррелируют с более высоким «риском» заболевания [2]. Существует некий средний уровень стресса, который считается оптимальным для поддержания здоровья. Причинами стресса у студентов могут быть финансовые трудности, проблемы с жильем, возрастные трудности и т.п. Воздействие стресса может проявляться в снижении способности к обучению, и как следствие, в академической успеваемости.

Дж.Гринберг [2] по вероятности возникновения стресса выделяет три группы «риска» среди студентов, это первокурсники и студенты старшего возраста, а также представители этнических меньшинств.

Первокурсники. Резкие изменения в стиле жизни, связанные с началом самостоятельной жизни. Привычная жизнь в родительской семье и отдых с друзьями сменяются на необходимость жить в другом городе или даже стране, в общежитии, учиться зарабатывать и расходовать деньги, полностью заботиться о себе; появляется новый круг знакомых и друзей. Студенты должны освоить новые роли и преодолеть трудности, которые могут быть связаны:

- с необходимостью достижения эмоциональной независимости от семьи;

- с выбором и подготовкой к профессиональной деятельности;

- с подготовкой к семейной жизни;

- с развитием этической системы ценностей.

Среди факторов учебной деятельности, вызывающих стресс у студентов младших курсов, прежде всего необходимо выделить следующие:

Экзаменационный стресс (экзаменационная тревога, связанная с со страхом неудачи; эмоциональные реакции в виде паники; значение, придаваемое оценкам).

Академическая перегруженность - состояние, вызванное избытком предметов или их повышенной сложностью. 
Дружба и любовь (расставание со старыми друзьями, знакомство и налаживание отношений с новыми, поиск любви и формирование отношений с противоположным полом).

Ревность (является стрессовым фактором и для того, кто ревнует и для того, кого ревнуют) и разрывы отношений (тяжелее переносят те, кого бросают и те, кто боится быть оставленным).

Секс (формирование отношения к сексу, информированность в области безопасного секса, риск заражения СПИДом и заболеваниями, передающимися половым путем).

Насилие (противостояние принуждению к сексуальной активности, предотвращение насилия).

Преодоление стеснительности.

Студенты старшего возраста, т.е. те, кто успел поработать, отслужить в армии, обзавестись семьей. Основные факторы стресса для них это:

- совмещение учебы, работы и семейных обязанностей;

- неуверенность в способности справиться с обучением.

Факторы стресса студентов, - представителей этнических меньшинств связаны в основном языковым барьером, проявлениями расизма, трудностями в адаптация к новым культурным нормам.

Вуз как социально-организационная среда реализации превентивных программ

Организация профилактической работы в вузе традиционно подразумевает в качестве основных направлений:

- обеспечение возможности для студентов получить психологическую помощь;

- разработка и внедрение программ по обучению управлению стрессом.

Роль обучающих программ не сводится сегодня лишь к управлению стрессом, наряду с ними необходимо разрабатывать программы обучения уверенному или ассертивному поведению. Концепция самоутверждения (ассертивности) предусматривает тактику отстаивания своей позиции и прав с помощью логических доводов, без нападок и агрессии, прислушиваясь к мнению собеседника, при необходимости с готовностью принимая компромиссное решение.

Искусство самоутверждения не подразумевает стремления к победе любой ценой, но заключается в самоуважении и уважении к другим. Ассертивное поведение помогает достичь поставленных целей без нанесения ущерба другим. Согласно этой концепции, человек должен самостоятельно делать выбор и отвечать за свои поступки. Такое поведение сопутствует внутренней уверенности и 
придает силы. Уверенность понимается как установка и поведение по отношению к самому себе.

На основе клинического опыта А.Лазарус [3] рассматривает четыре важнейших класса поведения, которые объединяет понятие уверенного, ассертивного поведения:

- способность сказать «нет»;

- способность открыто говорить о чувствах и ожиданиях;

- способность устанавливать контакты, начинать и оканчивать беседу;

- способность открыто выражать позитивные и негативные чувства.

Эти способности существуют не только на поведенческом уровне, но и на уровне когнитивных процессов, включая установки и жизненную философию. В обучающих программах работа проводится с тремя вариантами поведения:

- неуверенное (пассивное, без отстаивания своих прав, бегство): - человек стремится избежать конфликта путем сохранения статус-кво; позволяет другим принимать за себя решения; на словах соглашается с другими независимо оттого, что чувствует; тянет время, чтобы избежать необходимости решать проблему. При этом чувствует себя жертвой, винит других за то, что с ним происходит;

- агрессивное (прямая и косвенная агрессия, борьба): человек ведет себя агрессивно; пытается навязать свое мнение другим, невзирая на их чувства, ведет себя враждебно, непредсказуемо, «взрывается». Такая тактика помогает достичь поставленных целей до определенных пределов, за счет других людей. Агрессивное поведение предполагает высокую степень «риска», поскольку человек всегда оказывается на виду;

- уверенное (ассертивное, контроль, логика): — человек честен с самим собой и другими; защищает свои права, уважая права других; способен к социальному и эмоциональному самовыражению; уверен в себе; способен вести себя рационально, как зрелая личность. Такая тактика помогает достичь целей без причинения ущерба другим, делать выбор и отвечать за поступки.

В реализации превентивных программ в сфере наркотизма важную роль могут играть общественные движения и организации студентов.

Любое общественное движение предполагает принадлежность к нему, поэтому общественные объединения студентов, такие как общественные организации, студенческие центры и клубы могут 
выступать для них как одно из средств самоидентификации в позитивном контексте. Здесь удовлетворяется потребность молодежи в принадлежности к группе. Подобная идентификация с целями, ценностями и нормами референтной группы позволяет приобретать позитивный социальный опыт, который переноситься в другие сферы жизнедеятельности.

Общественные объединения, которые реализуют проекты, связанные с развитием просоциального поведения, где приветствуется уважение, ответственность, объективная оценка результатов, инициатива, поддержка выполняют важнейшую функцию воспитания будущих специалистов и граждан. Превентивные программы в области аддиктивного поведения могут быть реализованы общественными объединениями в рамках молодежных направлений своей деятельности.

Организация досуга в рамках представлений о здоровом образе жизни. В данных программах подход основан на предоставлении альтернативы в удовлетворении стремления молодежи к риску, поиску острых ощущений, активности. Это: спорт, путешествия, творчество.

Организация образовательных программ, направленных на:

- повышение уровня знаний о негативном влиянии наркотических веществ и последствиях их употребления;

- повышение коммуникативной компетентности и обучение жизненным навыкам и противодействи негативным влияниям сверстников. умение строить перспективные жизненные планы

- подготовка молодежных лидеров, которые выражают желание проводить антинаркотическую работу в среде сверстников.

Осуществление программ социальной помощи. Содержанием таких программ является обучение студентов основам медикосоциального сопровождения своей жизни и учебной деятельности.

Осуществление программ сотрудничества с другими студенческими движениями и организациями, имеющими сходные цели.

Таким образом, вуз как социальная организация имеет много рычагов и каналов влияния, которые могут быть успешно использованы для превенции наркотизма в студенческой среде.

\section{Литература}

1. Брижит Т. Право на здоровье. Теория и практика. М., 2001.

2. Гринберг Дж. Управление стрессом. М., 2002. 
3. Лазарус А. Краткосрочная мультимодальная психотерапия. СПб., 2001.

4. Лисовский В.Т., Социология молодежи. Учебник, СПб., 2001.

5. Помощь родителям в воспитании детей/ Под ред. Пилиповского В.Я., М., 1992.

6. Реан А.А. Психология. Учебник/Под ред. Крылова А.А., M., 2000.

7. Роджерс К., Фрейберг Д., Свобода учиться. М., 2002.

8. Шейн Ш. Организационная культура и лидерство. СПб., 2002. 